\title{
Mathematical literacy and Nigerian Stock Exchange: an exposition of financial information for Blue-chip stocks' business decision analysis
}

\section{Hashim Sabo Bello}

Department of Business Administration and Management, School of Management Sciences, Abubakar Tatari Ali Polytechnic Bauchi, Bauchi state, Nigeria.

\section{Mutari Haruna Dunari}

Department of Mathematics and Statistics, College of Science and Technology, Hussaini Adamu Federal Polytechnic, Kazaure, Jigawa Sate, Nigeria.

\begin{abstract}
In academic study, as in other walks of life, figures can give you a lot of detailed information quickly and efficiently, the time you invest in learning how to read tables and diagrams will save you a lot in your future decision making. You will become informed much more precisely and much more rapidly once you can take advantages of these figures, following this premise, the study aims to find out how figures are being used to analyses the hypotheses put forward by stock brokers to peg prices of shares, and as well identify and interpret what they are being used for in the Nigerian stock Exchange. Consequently, this review work was based on descriptive content analysis of mathematical literacy and the Nigerian Stock Exchange with particular emphasis on financial numeracy regarding Blue-chip stocks and business decision analysis thereby primary source are make use of. Hence, this study focused on the importance of meaning making in mathematical literacy to solidify the understanding of blue-chip stocks so as to achieve a better business decision making in the fast moving world. Besides, the paper examined the stock numeracy experiences and its implications for business decision analysis. Herein, the study believed that the mathematical literacy is a critical component in the education of our nation's youth especially in this era of economic recession and the study therefore recommended that the level of mathematical understanding will provides the necessary mathematical base for success in the world of business by positioning groundwork for mathematical literate citizens i.e. the intelligent investors to assess the profitability, survivability, growth, stability, dividend (if any), likely problems, risks and other factors which may affect his/her investment in a particular company.
\end{abstract}

Key words: mathematical literacy, blue-chip stocks, decision analysis, financial information, business investment.

\section{JEL Classification: G11.}

(C) The Authors, 2018. This article is published with open access at Sumy State University.

\section{Introduction}

Everyone is faced with one decision or the other to make in life i.e. what profession to choose, whom to marry, what to invest, what advertising media to adopt and so on, are some situations where decisions are to be made. Some of the decisions are very difficult to make because of the complexity of the situation especially in case of several business and industrial problems more and more complex (Uhaa, 1997). One of the aims of academic enquiry is to be able to describe aspects of the world-to sketch out key features and to outline what is going on. Imagine you were asked to describe ways in the Nigerian stock Exchange in the 1905 is different from that of ten to twenty years after. One very obvious feature you might pick on is the impact of modern technology. One might, for instance, point to the changes brought about by the enormous growth in the NSE which by implication analyzed the volume of trading activities brought about by the information especially when we come to terms with decision analysis.

For example, venture capitalists invest in young private companies and make their money when the companies mature and either float or are taken over by a trade buyer. Returns on this so-called private equity investing have historically been good - in the 20 percent per annum area - but the opportunity to invest in this way is usually only open to those with big money to invest. Private equity also depends for its existence on health public stock markets. Private investors can invest via specialist funds or listed private equity management companies like Candover and 3 i. 
In modern terms, for investors to make informed decisions, Bajomo and Ohaeri (2015) posited that investors have to express their emotions and reactions on the economy of countries through the Exchanges in those countries. The stock exchange serves as a conduit where those emotions and sentiment are expressed. It allows investors to make informed choices and also participate in the financial achievements of the companies and indeed countries whose shares they have chosen to be part of, providing the channel for ease of entry or exit by the investor. As we now live in the society where a great deal of information is communicated in the form of numbers, so a good decision must use scientific or analytical decision making principle base on logic in consideration and possible alternatives around to prepare a realistic analysis. Against the backdrop of the recent suspension and withdrawal of licenses of some stock broking firms in Nigeria, Salako (2015) posited that the Nigerian Stock Exchange (NSE) advised investors to follow proper procedures in transferring their securities, including shares, exchange traded funds and fixed income securities, from either suspended or inactive and expelled stock broking firms.

Hence, sometimes these figures come singly, as when the news readers tell us the equity prices of the blue chip stocks. Sometimes they come as sets of numbers which are presented together such as the cooking instruction for a chicken given temperatures and times weights. And sometimes lot of numbers are put together in the form of a chart or group, such as the diagram in the newspaper which summarize the result of the latest political opinion poll (Northedge, 2003). And or how the Naira has been rising and falling against the dollar, or which show how blue chip stocks drag equity prices down.

\section{Methodology}

This review work is based on descriptive content analysis of the Stock Exchange in Nigeria as an organized market with rules, oversight and various players involved in the movement of securities. The study takes place for academic purpose of exploring the core functions of mathematical literacy in ensuring fair and orderly trading of blue-chip stocks as well as efficient dissemination of price information for securities traded, leveraging on cutting-edge technology leading to better business decision analysis. It presents companies, governments and other groups with opportunities to sell and buy securities to the investing public. The proposed qualitative methodology will allow for deep practical insights as ethnography is an excellent research tool when there is limited empirical support (Genzuk, 1999; Gummesson, 2003). For that reason, the paper depends on literature survey of existing secondary source in that way the collection of relevant facts or information are mainly from books, magazines, and newspapers, etc., so as to arrive at logical conclusion and proffered suggestions as the article's potential contribution of the content study to fill certain gaps.

Review of related literature and relevant concept. The purpose of a research is to gather ideas from other intellects through their text-books, write-ups in magazines, newspapers, journals and other related media to compare, contrast and authenticate the result of the research study in question. It is a well-known fact that no man is an island or can be the house of all knowledge since knowledge is akin to a bush which comprises uncountable trees, no man can possess all. All these axioms point us to the fact that reviewing of literature is indispensable in any topic of research work. With the afore stated in mind, this research work will delve into people works on related topic, climb some salient points that will help in reaching an extensive analysis and conclusion which will pave leeway to resourceful and acceptable recommendations.

The purpose of this research work is to review the relevant concept and literature directly related to the mathematical literacy about issues concerning the Nigerian Stock Exchange to determine the extent to which it can be of used in the information age. This study aimed to looks at the individual's capacity for formulating, employing and interpreting mathematics in a variety of contexts such in the stock exchange market especially in Nigeria. It also aimed to study the stock exchange market by making mathematical deductions and applying mathematical concepts, procedures, facts and tools to describe, explain and predict phenomena in Nigeria.

Mathematical literacy is an individual's capacity to identify and understand the role that mathematics plays in the world, to make well-founded judgements and to use and engage with mathematics in ways that meet the needs of that individual's life as a constructive, concerned and reflective citizen (OECD, 2006). The competencies developed through Mathematical Literacy allow individuals to make sense of, participate in and contribute to the twenty-first century world - a world characterized by numbers, numerically based arguments and data represented and misrepresented in a number of different ways. Such competencies include the ability to reason, make decisions, solve problems, manage resources, interpret information, schedule events and use and apply technology. 
History and objectives of Stock Exchange in Nigeria. The Nigerian Stock Exchange was founded in 1960 as the Lagos Stock Exchange, on September 15, 1960, the stock exchange council was inaugurated. Operations began officially on August 25, 1961 with 19 securities listed for trading but informal operations had commenced earlier in June, 1961. Operations were initially conducted inside the Central Bank building with the exchange having four firms as market dealers: Inlaks, John Holt, C.T. Bowring and ICON (Investment Company of Nigeria). The volume for August, 1961, was about 80,500 pounds and it rose to about 250,000 pounds in September of the same year with the bulk of the investments in government securities. In December 1977 it became known as The Nigerian Stock Exchange, with branches established in some of the major commercial cities of the country (Wikipedia, 2018).

The Nigerian stock exchange is undoubtedly one of the most important contributors to the Nigerian economy. The number of investors is increasing. In simple terms, the Nigerian stock exchange is a market place. This is the place where you buy stock and sell stock. People trade in stocks and securities here. The idea is to buy stocks when their prices are low and sell them off when they appreciate considerably. Information is very important for the investor in order to know which stock to buy and when to sell such stock. A number of factors, like the history of the stock, its perception, cost and quality, can go a long way in determining which stock to be bought or sold off at any particular time. The stock trader needs to keep the stock with him/her after purchasing till the stock appreciates considerably in value (Nigerian Finder, 2018).

The Nigerian Stock Exchange has been operating an Automated Trading System (ATS) since April 27, 1999, with dealers trading through a network of computers connected to a server. The ATS has facility for remote trading and surveillance. Consequently, many of the dealing members trade online from their offices in Lagos and from all the thirteen branches across the country. The Exchange is in the process of establishing more branches for online real time trading. Trading on The Exchange starts at 9.30 a.m. every business day and closes at 2.30 p.m. (Wikipedia, 2018). They publish data of performance on companies listed $\mathrm{n}$ the Nigerian Stock Exchange on the Nigerian stock; such performance data are published on annual, quarter, monthly, weekly and daily basis. The dealers can use the system to monitor market activities without visiting the Nigerian Stock Exchange. Many of those dealing in the stock market do so right from their offices (Nigerian Finder, 2018). Here, mathematical literacy helps people to identify and understand the role that mathematics plays in the stock exchange world, and to make the well-founded judgements and decisions required in life by constructive, engaged and reflective citizens.

The legislation that was initially preventing foreign investors to operate in the ingrain stock exchange had been abolished by the Nigerian government. This means foreign companies can be listed on the Nigerian Stock Exchange and this enables Nigerians to invest in such companies. The Nigerian Stock Exchange was deregulated by the government in 1993. This means issues prices are now determined by stockbrokers and issuing houses. Stockbrokers alone determine prices of the secondary market (Nigerian Finder, 2018). The NSE is regulated by the Securities and Exchange Commission, which has the mandate of Surveillance over the exchange to forestall breaches of market rules and to deter and detect unfair manipulations and trading practices. The Exchange has an automated trading system. Data on listed companies' performances are published daily, weekly, monthly, quarterly and annually (Wikipedia, 2018).

The Nigerian stock exchange creates Medium via which investors in the Nigerian stock market can disposable income to buy products (stocks and securities) with the belief that such product will rise in value in the future. They are regulated by the Securities and Exchange Commission. This regulatory body has the mandate to ensure Surveillance over the activities of the Nigerian Stock Exchange. This helps to prevent breach of market rules. It also helps detect and deter unfair manipulations and trading practices (Nigerian Finder, 2018). According to Quadri (2017), the Nigerian stock exchange is undoubtedly one of the most important contributors to the Nigerian economy. Nigerian stock exchange is a market place where you can buy stock and sell it.

1. It protects the investing public from shady dealings and sharp practices through its rules, regulations and operational codes.

2. The exchange facilitates dealing in government securities.

3. Stock exchange encourages people to save.

4. The stock exchange serves as a medium for the dissemination of information to industrialists and investors.

5. They protect the public from sharp practice ad shady dealings by providing guiding rules.

Those are just few of the objectives. In line with this thinking, Ogunwale (2014) admitted that the bearish trend on the Nigerian stock Exchange ( NSE), which began since the first trading day of the week persisted 
all through the week following losses in the share price of most blue-chip companies at the end of the week , market capitalization on the Nigerian houses depreciated by $\$ 200$ billion or $1.4 \%$ from $\$ 14.163$ trillion to close out 13.963 trillion on Friday, while the NSE ALL- share index (NSE ASI) depreciated by 605.97 basis point s or $1.41 \%$ to close at $42,285.82$ basis points from $42,891.82$ point it opened.

Perception on mathematical literacy, stock market, stock trading and blue chip stocks. Given that the world is moving towards a knowledge based economy, the lack of mathematical literacy is a big concern. Now more than ever the ability to critically evaluate information presented to us to draw our own conclusions, rather than have someone tell us what they mean, is of the utmost importance. So far so good, a mathematical literacy is one of the most important need of an investor especially if he wants to be, an inside investor or a rich investor. Mathematical literacy has been defined in a wide variety of ways over the past few years and one thing everyone more or less has come to agree on is that mathematical literacy cannot be defined only in terms of mathematical knowledge. Mathematical literacy is in fact mainly about the functional aspect of mathematical knowledge. It is about individual competencies to use mathematical knowledge in a practical, functional way.

Hence, Jablonka (2003) classified different approaches of mathematical literacy, which she justifiably concluded that the differences in approach are directly linked with the goals that are pursued in mathematics education in individual realms. The first approach which concerns our topic of discussion focuses on equipping people with the mathematical tools to interpret and organize their day-to-day lives, "Mathematical literacy for developing human capital". The idea is that all kinds of problems can be modeled with mathematics and can subsequently be solved with mathematical techniques.

This approach is also used by the Organization for Economic Co-operation and Development (OECD), which defines mathematical literacy as follows: 'The capacity to identify, to understand and to engage in mathematics and make well-founded judgements about the role that mathematics plays, as needed for an individual's current and future private life, occupational life, social life with peers and relatives, and life as a constructive, concerned, and reflective citizen' (OECD, 1999).

Anyone who lacks mathematical literacy cannot see into an investment. When the mind is empowered via mathematical education, it will identify ways to make millions. Better still, financial intelligence helps to create wealth with little money. Just as a doctor uses X-rays to look at our skeletal system and via X-rays identifies a patient with cancer or tuberculosis, so does financial statement allow an investors to see the truth, facts, fictions, opportunities, and the risk. As a matter of fact, there are three (3) main relevant concepts in the Nigerian stock Exchange (NSE) which are discussed in details below, namely; stock market, stock trading and blue chip stocks.

The Stock Market: The word stock simply refers to a supply. You may have stock of frozen turkeys, chicken in your shelves (Stephen 2005a). In the financial market, stock refers to quantity of money that a company has raised. This supply comes from people who have given the company money in the hope that the company will make their money grow (Stephen, 2005b).

There are many stock exchanges located in every country around the world. The American Stock Exchange markets in the whole world. The two other main financial hubs are London, home of the "London Stock Exchange" and Hong Kong, home of the "Hong Kong Stock Exchange" representing the Asian Market. In Africa, the Nigerian Stock Exchange is next to the Johannesburg Stock Exchange (South Africa) Capacity wise (Stephen, 2005b).

The stock trading: Stock trading is the act of buying stocks at low prices and selling at high prices within a short period of time usually in less than 12 months. The essence of stock trading is to make profit from the capital market. Another objective of the stock trading is to make high return on investment than those who buy and hold for long term purpose and also stock traders, trade in stock on other to beat the general marketreturn on investment (Stephen, 2005a).

Trading in stocks or long-term stock investments are not without risks. For risks minimization and profit maximization, there is need for one to analyze the numerical information about the company's performance in the market place. Generally speaking, it is important for the investor to compare a company ratio's for the current year with that of previous years to measure the growth of the company. The investor should further compare the company's ratios with those of other companies in the same industry. Hence, trading stocks are stocks with regular oscillations of prices in the capital market (Stephen, 2005a). 
The Blue Chip Stocks: These stocks are simply referred to as Blue Chip and can otherwise, be referred to as growth stocks because the company has reached a steady way of growth in capacity, sales and profit (Stephen, 2005a). Thus the stock's price will also continue to grow in a steady manner. The stocks in this category are the most capitalized stocks in the capital markets. They have total assets worth above 20 Billion. Steady growth in net profit and turnover, steady but gradual expansion of business capacity, brands and sales, which have competitive advantage in their core business, high managerial competence and steady achievement of organizational performance (Stephen, 2005a).

Furthermore, Stephen (2005a) said that the price of these stocks often assume a steady rise with little oscillation and a very strong and fast capacity to rebound because of high demand. The stocks with high rate of capital appreciation among the Blue chips are those with low volume of shares like the petroleum marketing companies, e.g. Corn Oil, Oando, Total, Texaco and Mobil. Other are Nestle, Nigeria Breweries, Guinness Nigeria PLC, NBC, Cadbury, GTBank, FBN, UBN, UBA, Zenith Bank and Son on.

For instance, Nestle was $\$ 2$ by September 2003 but it went up to $\$ 174$ (almost double in less than Ten months), Cadbury from $\$ 41$ (September, 2003) to $\$ 72$ in May 2004, while Total PLC rose from $\$ 93$ by September 2003 to $¥ 207$ May 2004 (Stephen, 2005a). Still, like every other stocks in the capital market the price may drop anytime and may appreciate at any moment. Past performance is not a guarantee or yard stick for future return on investment. Your investment decision should be based on the advice of professionals.

Blue chips with high volume of shares are the banks and insurance companies. This is because the voluminous nature of banks/insurance firms' shares, high demand can hardly affect their price movement. Therefore capital appreciation is not usually significant some dividends policy is a very impressive way of the growth of one's investment. Most often, the shares of banks and insurance companies are readily available, hence it encourage stock trading. Regulatory authorities require high level of transparency in accountability in banking and insurance industries. Thus their compliance with this regulation has made these stocks toast of investors any day because the information about these companies are usually available in the Newspapers (Stephen, 2005b).

Relevance of numerical information in describing the Nigerian Stock Exchange. There's a culture among school kids to dislike math and the perception that it's largely useless. While in chemistry you can see stuff blow up, and in biology you can dissect animals, math is a largely abstract concept. That perception then manifests as a lack of interest, which results in poorer performance, and that puts people off math. This is further compounded by phenomena known as "Math Anxiety" or "Math Phobia". Ashcraft and Kirk (2001) discuss and suggest that much of the anxiety is a result of the fear of getting the wrong answer in their tests.

Making sense of figures is a normal part of modern life. Numbers help us to give weight and form to descriptions of society by showing the dimensions and the scale of social phenomena. Gompers and Lerner (2003) cited in Sulaiman (2013) conceived that economists establish prices are determined by the forces of demand and supply in a free economy. In the securities market, the price of equity is significantly influenced by a number of firm, dividend per share, earnings per share, price earnings ratio and dividend cover.

Learning the terms of mathematics need not be a burden. Don't fall into the trap of thinking in terms of the equation: social science $=$ research $=$ data $=$ numbers, sets of numerical data can be presented in many different ways to aid clarity and better understanding. Although they may look very different forms, in tabular, charts, graphs, and diagrams can all be used to present exactly the same information. Mathematical measurements are natural part of human activity; they have connections to the real world.

Congruently, Aminu (1995) think that, in the social and management sciences especially, in business and accounting, the new technique of presentation of accounting information such as profit and loss accounts and balance sheet are now presented in a form of diagrams and graphs for easy understanding of shareholders with or without accounting skills. The OECD (2000) released a report where it reveal that, Quantitative literacy the knowledge and skills required to apply arithmetic operations, either alone or sequentially, to numbers embedded in printed materials, such as balancing a cheque book, figuring out a tip, completing an order form or determining the amount of interest on a loan from an advertisement.

1) Describing blue-chip stocks in Nigerian Stock Exchange with tables. In making sense of Mathematical Literacy, this paper provides opportunities to develop and practice decision-making and communication skills by utilizing tables. The purpose of these tables is the presentation of information or data for the understanding of the user and also in a more attractive, appealing and colourful to enable the reader have a general perspective 
of the data on display for easy comprehensiveness. Mathematical literacy involves the use of integrated content and/or skills in solving problems especially as obtainable in trading in equities in the Nigerian stock exchange, as more investors took position on stocks.

Specifically, the All Share Index appreciated $2.13 \%$ to close at 31,744.82 points, compared to the increase of $1.69 \%$ recorded the preceding day to close at $31,082.48$ points. Market capitalization gained $\$ 224$ billion to close at $\$ 10.7$ trillion, higher than the increase of $\$ 175$ billion the preceding day to close at $\$ 10.5$ trillion (Anonymous, 2015)

Table 1. Stock updates: GAINERS

\begin{tabular}{|l|c|c|c|c|}
\hline \multicolumn{1}{|c|}{ Company } & Opening & Closing & Change & \% Change \\
\hline Ashaka Cement & 18.50 & 20.39 & 1.89 & 10.22 \\
\hline Champion & 6.38 & 7.02 & 0.64 & 10.03 \\
\hline Corn Oil & 35.60 & 39.13 & 3.53 & 9.92 \\
\hline Fidelity Bank & 1.57 & 1.72 & 0.15 & 9.55 \\
\hline Total & 165.00 & 180.00 & 15.00 & 9.09 \\
\hline NASCON & 6.90 & 7.50 & 0.60 & 8.70 \\
\hline First City Monument Bank & 2.66 & 2.88 & 0.22 & 8.27 \\
\hline NAHCO & 5.44 & 5.81 & 0.37 & 6.80 \\
\hline Zenith Bank & 19.87 & 20.98 & 1.11 & 5.59 \\
\hline Intbrew & 18.00 & 18.90 & 0.90 & 5.00 \\
\hline
\end{tabular}

Source: capital market (2015).

As a matter of fact, Ashaka Cement PLC led the gainers table with $\$ 1.89$ or 10.22 percent to close at $\$ 20.39$ per share, followed by Champion Breweries PLC with 64 kobo or 10.03 percent to close at $\$ 7.02$ per share. Con Oil PLC added $\$ 3.53$ or 9.92 percent to close at $\$ 39.13$ per share, while Fidelity Bank PLC. was up 15 kobo or 9.55 percent to close at $\$ 1.72$ per share. Total rose $\$ 15.00$ or 9.09 percent to close at $\$ 180.00$ per share.

Table 2. Stock updates: LOSERS

\begin{tabular}{|l|c|c|c|c|}
\hline \multicolumn{1}{|c|}{ Company } & Opening & Closing & Change & \% Change \\
\hline REDSTAREX & 3.75 & 3.60 & -0.15 & -4.00 \\
\hline WAPIC & 0.52 & 0.50 & -0.02 & -3.85 \\
\hline Diamond Bank & 4.18 & 4.05 & -0.13 & -3.11 \\
\hline Sky Bank & 2.46 & 2.40 & -0.06 & -2.44 \\
\hline FBNH & 8.90 & 8.70 & -0.20 & -2.25 \\
\hline Sterling Bank & 2.20 & 2017 & -0.03 & -0.33 \\
\hline Eterna & 3.06 & 3.05 & -0.01 & -0.25 \\
\hline Seplat & 399.00 & 398.00 & -1.00 & -0.06 \\
\hline ETI & 18.01 & 18.00 & -0.01 & \\
\hline
\end{tabular}

Source: Capital Market (2015).

Conversely, Red Star Express Plc. shed 15 kobo or 4\% to close at $\$ 3.60$ per share, while Wapic Insurance PLC cost two kobo or $3.85 \%$ to close at 50 kobo per share. Diamond Bank PLC fell 13 kobo or $3.11 \%$ to close at $\$ 4.05$ per share, while Skye Bank PLC depreciated six kobo or $2.44 \%$ to close at $\$ 2.40$ per share.FBN Holdings PLC lost 20 kobo or $2.25 \%$ to close at $\$ 8.70$ per share. A total of 379.5 million shares valued at N5.05bn were traded in 4,138 deals.

Describing blue-chip stocks in Nigerian Stock Exchange with diagrams/graphs. Following price gains recorded by most blue chip companies, equities trading on the Lagos floor of the Nigeria Stock Exchange yesterday sustained rising profile, causing market capitalization to appreciate by N221 bn. The market capitalization of listed equities, which opened the day's business at N10.496tr, went up by $2.10 \%$ to N10.717tr (Anuforo, 2015).

Also, the NSE All share Index grew by 654.01 basis points to 31,744.82 points from 31,090.81 points traded the previous day (Anuforo, 2015). The volume of trading activities increased by N183.196.453 million or 93 percent as investors bought 379.353 million shares worth $\$ 5.053$ billion shares valued at $\$ 1.837$ billion exchanged in 3, 638 deals. 


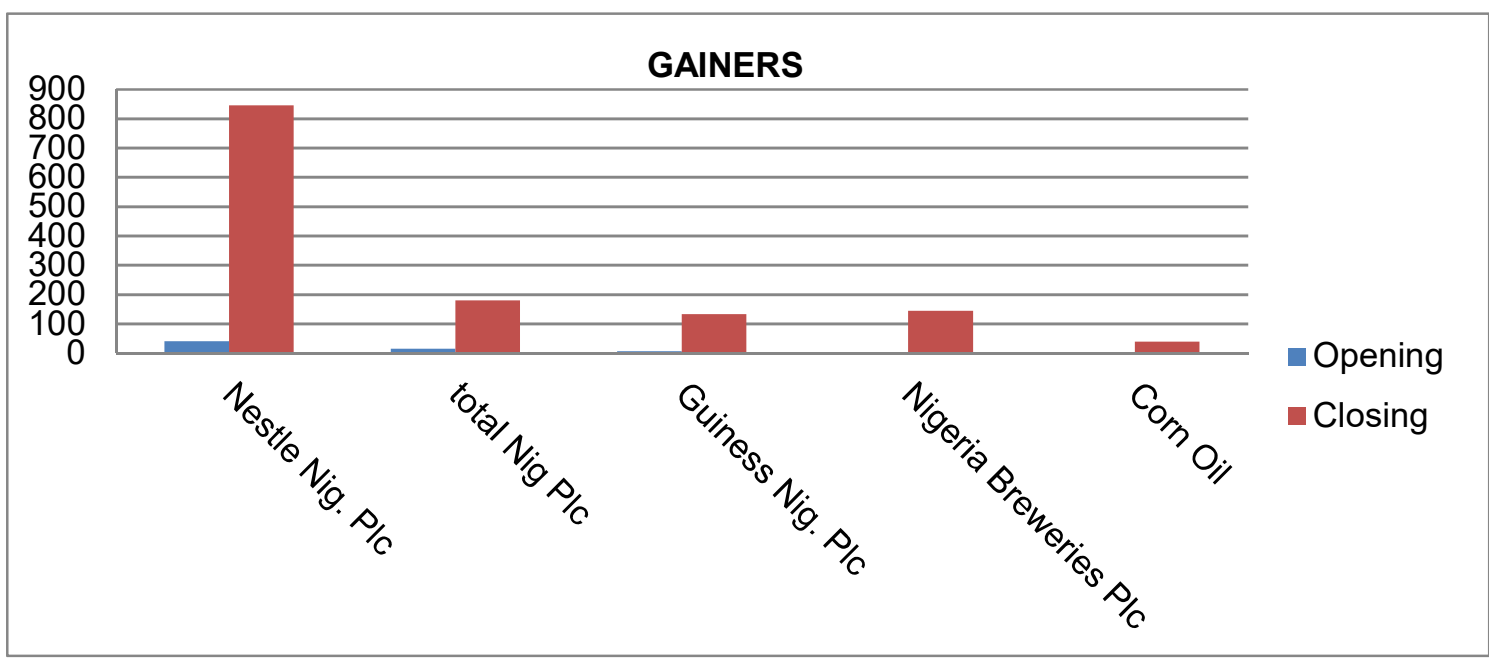

Figure 1. Stock updates: GAINERS

Source: Daily Sun Newspaper (2015).

An analysis of yesterday's trading showed that Nestle Nigeria Plc led the gainers table for the day, increasing by $\$ 40.00$ to close at N845.00. Also, Total Nigeria with $\$ 15.00$ to close at $\$ 180.00$ while Guinness Plc. gained $\$ 6.19$ kobo to close at $\$ 132.19$ kobo. Nigeria Breweries Plc. appreciated by $\$ 3.70$ kobo to close at $\$ 143.70$ kobo and Corn Oil increased by $\$ 3.53$ kobo to close at $\$ 39.13$ kobo (Anuforo, 2015).

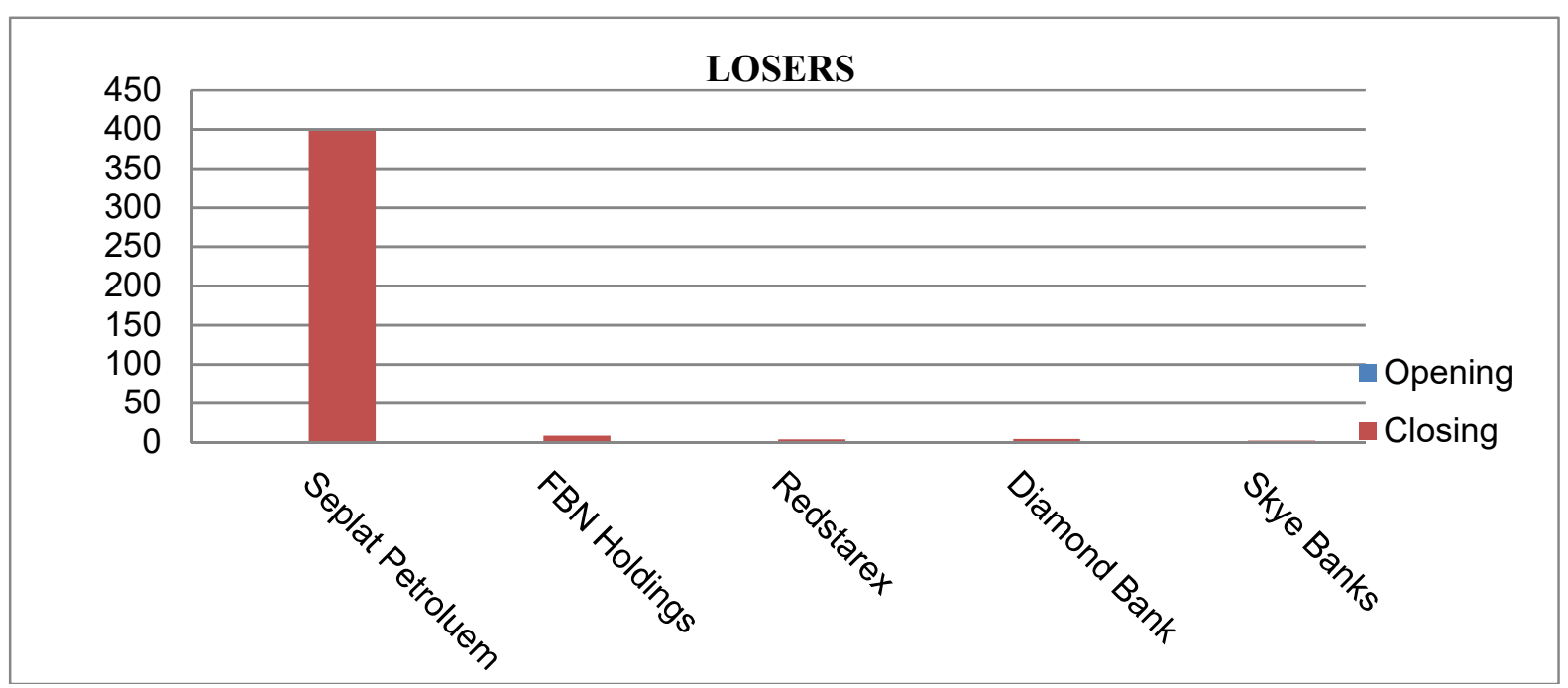

Figure 2. Stock updates: LOSERS

Source: Daily Sun Newspaper (2015).

On the contrary, Seplat Petroleum Development topped the losers chart, dropping by $\$ 1.00$ to close at \#398.00; FBN Holdings trailed with a loss of $\$ 0.20$ kobo to close at N8.70 kobo while RedStarex declined by $\$ 0.15$ kobo to close at $\$ 3.60$ kobo. Other company that depreciated in price was Diamond Bank which fell by $\$ 0.13$ kobo to close at $\$ 14.05$ kobo and Skye bank dropped by $\$ 0.06$ Kobo to close at $\$ 2.40$ kobo (Anuforo, 2015).

Describing Blue-chip stocks in Nigerian Stock Exchange with percentage/fractions. It is useful to be able to switch back and forth between fractions and percentages because, although percentages are more accurate, you can begin to lose touch with what the figures mean. If you remind yourself from time to time that 50 percent is the same as a half, that 75 percent is three - quarters, that 20 percent is faith and so on, it helps to fix in your mind the kinds of quantities you are dealing with (Northedge, 2003). Transactions on the Nigerian Stock Exchange (NSE) continue with its impressive performance at the end of the week trading. The summery of trading for the week indicates that the NSE All Share Index and market capitalization appreciated by 370.90 
basis points or 0.96 percent to close on Friday at 39,083.66 and $\$ 199$ billion or 0.96 percent to close at $\$ 12.554$ trillion respectively (Ogunwale, 2014).

NSE food and Beverages Index records 0.24 percent to emerge the most active sectoral performance among others while NSE Banking Index is the least hit with 0.80 percent loss. Added to this, NSE Banking Index records 1.43 percent to emerge the most active sectoral performance among others while NSE Oil and Gas Index is the least hit with 0.37 percent loss (Ogunwale, 2014). Hence, Ibrahim (2015) said that, market breadth closed positive as Ashaka cement led 41 gainers against 91 losers topped by Red star Express at the end of yesterday's session an improved performance when compared with previous outlook. Market turnover closes positive as volume moved up by $+93.34 \%$ against $-58.75 \%$ decline recorded in the previous session. Access bank, Diamond and FBNH were the most active to boost market turnover. Dangote cement and GTB top market value list (Ibrahim, 2015). NSE Banking records $+3.53 \%$ gains to emerge the most supportive sectoral index among others while NSE ASEM emerged as worst hit to close with $0.00 \%$ (Ibrahim, 2015).

Implication for numerical information in business decision analysis. As this paper is not going to delve into the whole area of math performance, both in terms of math anxiety and performance anxiety but we can't ignore the relevance of numerical information to add up the performance of blue-chip stocks in order to make a wise investment decision.

In sketching inference about the mathematical information, Northedge (2003) provided that the numerical information is information in a very condensed and highly abstract form. A number on its own means very little. You have to learn how to read it. You have to find out but how the number is used (i.e. what stands for thirty years ago, 51 was a very meaningful sign in Britain. Now the convention for representing that quantity is $25 \mathrm{p}$ or 80.25 . It is hard to imagine 51 - being the natural way of writing it, we have learned the new conventions so the roughly. Numbers of any kind are only meaningful to people who have learned how to read them. In many subjects of study you will come across numerical information in various forms. However, one may be tempted to immediately skip the numbers, tables and diagrams because they don't immediately convey a lot to someone, because of the initial effort required to learn how to read them.

In making investment decision, information about the company's performance in the market place is very important. The information is categorized into various classes such as current interim result, five year average earnings per shares, share price performance, market capitalization and so on (Stephen, 2005a). Each category should be analyzed diligently by taking the example of stock news, for instance, Ogunwale (2014a) hypothesize that "The NSE Insurance Index records 1.08 percent to emerge the most supportive sectoral performance among others while the NSE oil and Gas index is the most hit with 1.34 percent loss during the day trading." To invest well, one must be current and up to date with company/corporation performance analysis. Each time you come across a new kind of numerical information, the question arise as to whether it is worth making a fresh investment in learning how to make the numbers meaningful to you. Since there is so much numerical information around these days, the answer will often be no. You are unlikely to have the time to discover the significance of all the numbers you come on the backs of bottles, on the packaging of technical equipment, in the financial pages in Newspapers, and so on. On the other hand, within any given area of knowledge there is quite often a general level of numerical 'literacy' which is taken for granted. So if you intend to become a regular participant in discussions within that field, then you have taken the time and trouble to develop the relevant 'numerically'. If you want to play stocks and shares, for example, you have to be prepared to learn how to read the Financial Times Share Index (Northedge, 2003).

Conclusion and recommendations. As obtainable in all economies of the world, the stock market is the barometer of the economy. It measures the dynamics of economic and political interplay within the economy and a forward indicator of where the economy is headed. Most of the time, whatever direction the stock market goes, is totally dependent on the health of the various sectors of the economy that are represented by the various companies classified according to the industries they belong. It is where investors express their emotions or reactions, or put differently, cast their vote, regarding the performance of the companies in which they have shares or stakes in. Sometimes these emotions could be speculative, personal or based on facts and figures made available by these companies as part of their statutory post listing requirements (Bajomo and Ohaeri, 2015). Since the focus in Mathematical Literacy is on making sense of real-life contexts and scenarios to weigh up options by comparing solutions, make decisions regarding the most appropriate choice for a given set of conditions, and communicate decisions, so the paper recommend that, for investors to buy and sell shares in Nigeria, they must be ready learning stock numeracy. It's worthy of note that the stock numeracy is 
not a single ability which you either have or don't have. It is the skill, experience, and knowledge you need to "read" the specific kinds of numbers and table, used within a particular field of discussion. One can be "innumerate" in another area, such as the financial times share index. As we have already seen, we all display a wide-ranging "numeracy" in our daily lives, without even noticing it. We tend to be much more aware of the numbers we don't understand as appears in Nigerian Stock Exchange.

\section{References}

1. Aminu, A.A. (1995). Statistics for Social and management Sciences: Second Edition. Maiduguri: Government Printing press.

2. Ashcraft, M. H. \& Kirk, E. P. (2001). The Relationships among Working Memory, Math Anxiety, and Performance. Journal of Experimental Psychology: General. Pp. 224-237

3. Bojomo, A. and Ohaeri, K. (2015).Stock exchange as the ultimate voting machine (1).The Nation Newspaper, 10(3227). Lagos: Vintage Press Limited. Wednesday, May 27.

4. Anuforo, C. (2015). Market sustains momentum gains $\$ 221$ bn. Daily Sun Newspaper, Vol. 10(3111), Wednesday, April 1.

5. Capital Market (2015). Stock Updates. National Mirror Newspaper, 5(1081), Wednesday, April 1.

6. Genzuk, M. (1999).A Synthesis of Ethnographic Research. Available online from http://wwwref.usc.edu/wgenzuk/Ethnographic Research.html. Retrieved on 04/05/2014.

7. Gummesson, E. (2003). All Research in Interpretive. Journal of Business and Industrial Marketing, 482-492.

8. Jablonka, E. (2003). Mathematical Literacy. In A.J. Bis-hop, M.A. Clements, C. Keitel, J.

9. Kilpatrick \& F.K.S. Leung (Eds.). Second International Handbook of Mathematics Education (pp. 75-102). The Netherlands, Dordecht: Kluwer Academic Publishers.

10. Nigerian Finder (2018). Functions of the Nigerian Stock Exchange. Available online at: https://nigerianfinder.com/functions-of-the-nigerian-stock-exchange/ . Retrieved 31st May, 2018.

11. Northedge, A. (2003). The Good Study Guide. The Open University. Lagos: Express Image.

12. Ogunwale, K. (2014a). Blue Chip Stocks drag Equity Prices down by $\$ 200 \mathrm{bn}$. The Weekly

Trust Newspaper, Saturday, July 26. Pp. 57

13. Ogunwale, K (2014b). Stock Market maintains Positive posture with $199 \mathrm{bn}$ gain, weekly paper, 17(38), Saturday, April 12.

14. Okanlawon, J (2015). Equities record 2\% gain. National Mirror Newspaper,5(1081), Wednesday, April 1.

15. Organisation for Economic Co-operation and Development (OECD) (1999). Measuring

16. Student Knowledge and Skills: A New Framework for Assessment, (p.50). France, Paris: OECD.

17. Organization for Economic Co-operation and Development (OECD) (2000). Literacy in the Information Age: Final report of the International Adult Literacy Survey. Available online at: http://www.oecd.org/education/educationeconomyandsociety/39437980.pdf Retrieved on 28/11/2016.

18. Organization for Economic Co-operation and Development (OECD) (2006). Assessing Scientific, Reading and Mathematical Literacy: A Framework for PISA 2006. Available online at: http://www.oecd.org/pisa/pisaproducts/pisa2006/37464175.pdf. Retrieved on 28/11/2016.

19. Quadri, M. (2017). What are the objectives of the Nigerian stock exchange, and when was it created? Available online at: https://www.quora.com/What-are-the-objectives-of-the- Nigerian-stock-exchange-and-whenwas-it-created. Retrieved 31st May, 2018

20. Salako, T. (2015). Stock Exchange advises Investors on Procedures for Account transfer. The Nation Newspaper, 10(3227). Lagos: Vintage Press Limited. Wednesday, May 27.

21. Stephen, C.M. (2005a). Understanding the ABC of Stock investment. Michika: The Stock Millionaires Solutions.

22. Stephen, C.M. (2005b). Understanding how to open a new Stream of income via Stock investment. Michika: The Stock Millionaires Solutions.

23. Sulaiman, B.D. (2013). Assessment of the impact of Liquidity on Market price of ordinary shares of manufacturing companies in the Nigerian Stock Exchange. Nigerian Journal of Management and Development, 4(1), June.

24. Uhaa, A. (1997). Lecture notes on Analysis for Business decision. Department of Business Administration, Ahmadu Bello University, Zaria. Unpublished.

25. Wikipedia (2018). Nigerian Stock Exchange. Available online at: https://en.wikipedia.org/wiki/Nigerian_Stock_Exchange. Retrieved 31st May, 2018 